\title{
KINETIC STUDIES OF AMPICILLIN ACTION ON ESCHERICHIA COLI AND THEIR SPHEROPLASTS
}

\author{
A. E. Elkhouly*† and C. FüHrer \\ Institut fur Pharmazeutische Technologie der TU, \\ Braunschweig, Deutschland \\ (Received for publication January 12, 1978)
}

\begin{abstract}
Kinetic studies of ampicillin action were made on exponentially growing Escherichia coli and on $E$. coli-spheroplasts using a range of inhibitory and subinhibitory concentrations of ampicillin. For each concentration, the value $\left(k_{0}-k_{a}\right)$ representing the difference in generation rates of ampicillin-free culture $\left(k_{o}\right)$ and the generation rate of the culture with ampicillin $\left(k_{a}\right)$ was calculated and plotted against ampicillin concentration. A straight line relation was obtained with $E$. coli cells, its intersection with the abscissa, where $\left(k_{o}-k_{a}\right)=0$, give the concentration of ampicillin which exerts no inhibitory action on the cells $(0.25 \mu \mathrm{g} / \mathrm{ml})$. When $k_{a}$ was plotted against ampicillin concentration, the relation was also linear. Its intersection with the abscissa gives the minimum lethal concentration of ampicillin on the bacterial cells $(1.05 \mu \mathrm{g} / \mathrm{ml})$. With $E$. coli-spheroplasts such plots were non-linear which means that a different order of reaction was involved. This difference is probably due to a different mechanism of ampicillin action as revealed by the electroscanning microscopy.
\end{abstract}

Generation rates of growing cultures containing subinhibitory concentrations of antibacterial agents have been used as parameters to study the kinetics of the effects of these agents and to predict the mechanism of their antimicrobial activity ${ }^{1 \sim 5)}$. Kinetic studies were made on chemotherapeutic agents $^{31}$, and some antibiotics ${ }^{6,7)}$. With ampicillin, however, no such studies were reported. For this purpose, the action of ampicillin at different concentrations was measured against Escherichia coli growing cells and E. coli-spheroplasts. Furthermore, the action of ampicillin on E. coli-spheroplast was elucidated using the electroscanning microscope.

\section{Theory}

In order to study the kinetics of ampicillin action on $E$. coli, the generation rates of the bacterial growth without ampicillin and in the presence of ampicillin were determined from the generation-time curves and the following equations: Since E. coli during its course of multiplication followed an exponential order, then

$$
S_{f}=S_{0} \mathrm{e}^{k_{0} t}
$$

where $S_{0}$ is the initial number of survivors, $S_{f}$ is the number after time $t$ in the absence of ampicillin and $k_{0}$ is the generation rate. In the presence of ampicillin, the generation rate $\left(k_{0}\right)$ decreases and with some concentrations has a negative sign indicating a lethal effect. Thus the relation could be represented as

$$
S_{a}=S_{0} \mathrm{e}^{k_{a} t}
$$

where $S_{a}$ is the number of survivors after the same time $t$, in the presence of ampicillin, and $k_{a}$ is the apparent generation rate. In order to determine the change in the generation rates of the bacterial

* Present address: Department of Pharm. Microbiology, Faculty of Pharmacy, University of Alexandria, Alexandria, Egypt

+ To whom correspondence should be addressed. 
growth due to the effect of a specific concentration of ampicillin, equation (1) was divided by (2) thus

$$
S_{f} / S_{a}=\mathrm{e}^{\left(k_{0}-k_{a}\right) t}
$$

and

$$
\ln S_{f}-\ln S_{a}=\left(k_{0}-k_{a}\right) t
$$

Therefore, the plot of the logarithm of the ratio $S_{f} / S_{a}$ as a function of time represent a straight line which has a slope equal to the value $k_{0}-k_{a}$.

\section{Materials and Methods}

Materials

Ampicillin was supplied by Bayer, Leverkusen West Germany, $857 \mu \mathrm{g} / \mathrm{mg}$. Potassium salt of benzyl penicillin was obtained from Serva, Feinbiochemica, Heidelberg, W. Germany, 1,538 units/mg, and penicillinase from Riker Pharma, GmbH Borken Wesfalen, Deutschland. Escherichia coli, type 1 $\left(\mathrm{IMViC}++--, 44^{\circ}+\right)^{8)}$

Growth media

Nutrient broth, $16 \mathrm{~g} /$ liter (Merck, Darmstadt, Deutschland) adjusted to $\mathrm{pH} 6.7$ with phosphate buffer. Nutrient agar, nutrient broth (Merck) $16 \mathrm{~g} /$ liter supplemented with Ion agar No. 2 (Oxoid) $1 \%$. Spheroplasts media; Spheroplasts growth (SG) broth g/liter: Neopeptone (Difco Lab. Detroit, Michigan, USA) 15.0, yeast extract (Difco) 3.0, sucrose 105, magnesium sulphate 2.0, pH 7.0. Spheroplasts nutrient (SN) broth $\mathrm{g} /$ liter: nutrient broth (Merck) 16.0, sucrose 105, magnesium sulphate 2.0 adjusted to $\mathrm{pH} 6.7$ with phosphate buffer. All spheroplasts media when measured with an osmometer read osmotic pressures of 500 550 Milli-osmosis. (Halbmicro-osmometer type M Knauer, Deutschland). All nutrient media were sterilized by autoclaving at $121^{\circ} \mathrm{C}$ for 15 minutes.

\section{Methods}

Preparation of bacterial cultures: A 5-ml nutrient broth was inoculated with the organism from a fresh slant and incubated at $37^{\circ} \mathrm{C}$ for $14 \sim 16$ hours. A sample of $0.5 \mathrm{ml}$ was then transferred into $25 \mathrm{ml}$ nutrient broth in $50-\mathrm{ml}$ screw capped bottle and maintained at $37^{\circ} \mathrm{C}$ in a constant temperatureshaker-water-bath (Köttermann, KG, Deutschland) for 3 hours to obtain a viable count of $\mathrm{ca} .4 \times 10^{8}$ cells $/ \mathrm{ml}$. An aliquot of this culture equivalent to $1 \mathrm{ml} / 100 \mathrm{ml}$ broth, was transferred to a bulk amount of nutrient broth at $37^{\circ} \mathrm{C}$ and contained in a flask fitted with a $50-\mathrm{ml}$ glass dispenser. Fifty $\mathrm{ml}$ portions of the seeded nutrient broth were then transferred with the aid of the dispenser into sterile screw capped $100-\mathrm{ml}$ bottles and maintained at $37^{\circ} \mathrm{C}$ in the shaker-water-bath.

Immediately after distributing the seeded broth into the bottles, 1-ml sample from each was withdrawn and a viable count was made.

Effect of ampicillin concentrations on the generation rates of E. coli

Fresh solutions of ampicillin were aseptically prepared in phosphate buffer at $\mathrm{pH} 6.7,1-\mathrm{ml}$ aliquots of the ampicillin solutions were added to $49 \mathrm{ml}$ seeded broth during the logarithmic phase, usually after 30-minute incubation. At the same time, replicates of the seeded broth but without ampicillin were equally tested. At suitable time intervals, 1-ml samples were withdrawn from each culture, diluted with $0.9 \%$ sodium chloride solution and counted using the pour plate technique (from each sample 3 plates were made for viable count). The plates were incubated at $37^{\circ} \mathrm{C}$ for 48 hours and the developed colonies were counted.

Preparation of spheroplasts culture

A method similar to that described by HiRoKaWA ${ }^{15)}$ was used. Ten ml nutrient broth was inoculated with a loop-full of $E$. coli taken from a nutrient agar slope culture and the broth was incubated at $37^{\circ} \mathrm{C}$ with shaking for 16 hours. The culture was then diluted five-fold with SG broth containing $1 \mathrm{mg} / \mathrm{ml}$ benzyl penicillin, and was left in the shaker at $37^{\circ} \mathrm{C}$ for 4 hours, where a fresh amount of benzyl penicillin was added $(0.5 \mathrm{mg} / \mathrm{ml})$ and the culture was shaken for another 2 hours at $37^{\circ} \mathrm{C}$. The culture was then stored without shaking for 16 hours at $4^{\circ} \mathrm{C}$. The suspension was centrifuged at $1,500 \mathrm{~g}$ for 20 minutes at $20^{\circ} \mathrm{C}$ and the deposited spheroplasts resuspended in SG broth. To inactivate the penicillin, $0.15 \mathrm{ml}$ 
of a penicillinase solution $(400,000 \mathrm{u} / \mathrm{ml})$ was then added to the spheroplasts suspension and left at $20^{\circ} \mathrm{C}$ for 60 minutes. The inactivation of penicillin in the suspension was confirmed by agar diffusion assay using Staphylococcus aureus NCTC 4163 as the assay organism. The spheroplasts were twice centrifuged at $1,500 \mathrm{~g}$ for 20 minutes and resuspended in fresh SG broth to remove any penicillinase. The absence of penicillinase activity was confirmed by mixing an aliquot portion of the spheroplasts supernatant solution with an equal volume of $100 \mu \mathrm{g} / \mathrm{ml}$ ampicillin solution and the ampicillin activity was then checked by comparing the inhibition zone produced with that of $100 \mu \mathrm{g} / \mathrm{ml}$ ampicillin solution mixed with equal volume of SG broth containing no penicillinase. Finally the spheroplasts were suspended in $\mathrm{SN}$ broth, standardised to give a count of $c a .2 \times 10^{7}$ spheroplasts $/ \mathrm{ml}$ and were used within 24 hours for generation rate measurements.

Examination of the spheroplasts

The prepared spheroplasts suspension when examined under a phase-contrast microscope has shown rounded bodies of different sizes. In all samples examined, the normal rod-shaped cells of E. coli were not observed.

Effect of ampicillin concentration on the generation rate of E. coli spheroplasts

Fresh solutions of ampicillin were aseptically prepared in SN broth and 45-ml quantities were placed in screw capped bottles. The SN broth was then inoculated with $5 \mathrm{ml}$ of the spheroplasts culture and was left at $37^{\circ} \mathrm{C}$ in a shaker-water-bath. Samples were withdrawn at intervals ( $15 \sim 30$ minutes), diluted with $0.9 \%$ sodium chloride solution and a viable count was made using SN agar.

Preparation of samples for the electroscanning microscope

Samples were taken, fixed and stained for examination under the electroscanning microscope (Stereoscan 600 Cambridge) according to the method described by GREENwOOD \& O'GraDY ${ }^{91}$. A $2.5-\mathrm{ml}$ aliquot from each culture was mixed with equal volume of a fixer consisting of $10 \%$ sucrose and $2.0 \%$ glutaraldehyde and left overnight at $4{ }^{\circ} \mathrm{C}$. The suspension was then centrifuged at $1,500 \mathrm{~g}$ for 20 minutes, washed with distilled water 3 times and finally suspended in $1.0 \mathrm{ml}$ water. Droplets of each suspension were then placed on a glass cover-slip previously attached to an electron microscope stab. The droplets were air-dried and stained with $1.0 \%$ ferric chloride solution for 10 minutes, rinsed with 2 changes of distilled water and finally dried in a dessicator. The dried preparations were then coated with a thin-layer of carbon followed by a thin-layer of gold and examined under the electroscanning microscope.

\section{Results}

\section{Effect of Ampicillin Concentration on Growing E. coli Cells}

The minimum inhibitory concentration of ampicillin was $4 \sim 6 \mu \mathrm{g} / \mathrm{ml}$ using inoculumn of $4 \times 10^{6}$ cells $/ \mathrm{ml}$. This concentration was also reported by other workers ${ }^{10,11}$. In this work, therefore, the kinetics studies were made using ampicillin concentrations upto $4.0 \mu \mathrm{g} / \mathrm{ml}$. The results obtained are presented in Fig. 1. Each point is the average of 6 different replicates. From Fig. 1, the effect of ampicillin was lethal when used at concentrations higher than $1.0 \mu \mathrm{g} / \mathrm{ml}$. Although the antibiotic was used at concentrations below the MIC, however, lower viable counts were obtained shortly after the inclusion of the ampicillin. In this respect, ampicillin behaves differently from other antibiotics like tetracyclines $^{6)}$, sodium fusidate ${ }^{5 /}$ and lincomycin ${ }^{7)}$ when similarly tested.

\section{Effect of Ampicillin Concentration on E. coli Spheroplasts}

The ability of the spheroplasts to revert to normal cells and form visible colonies on nutrient agar was used here to measure the response of the spheroplasts to the ampicillin action. LEDERBERG ${ }^{121}$ has shown that E. coli spheroplasts reverted into rods when the penicillin was removed from the medium. Thus the spheroplasts form visible colonies only after their reversion and after being capable to divide like the normal cells ${ }^{161}$. The effect of different concentrations, upto $100 \mu \mathrm{g} / \mathrm{ml}$, of ampicillin on E. coli- 
Fig. 1. Generation-time curves of $E$. coli culture in the absence and in the presence of $0.25,0.5,1.0$, $1.5,2.0$ and $4.0 \mu \mathrm{g} / \mathrm{ml}$ ampicillin.

The arrow indicates the time at which the ampicillin was added.

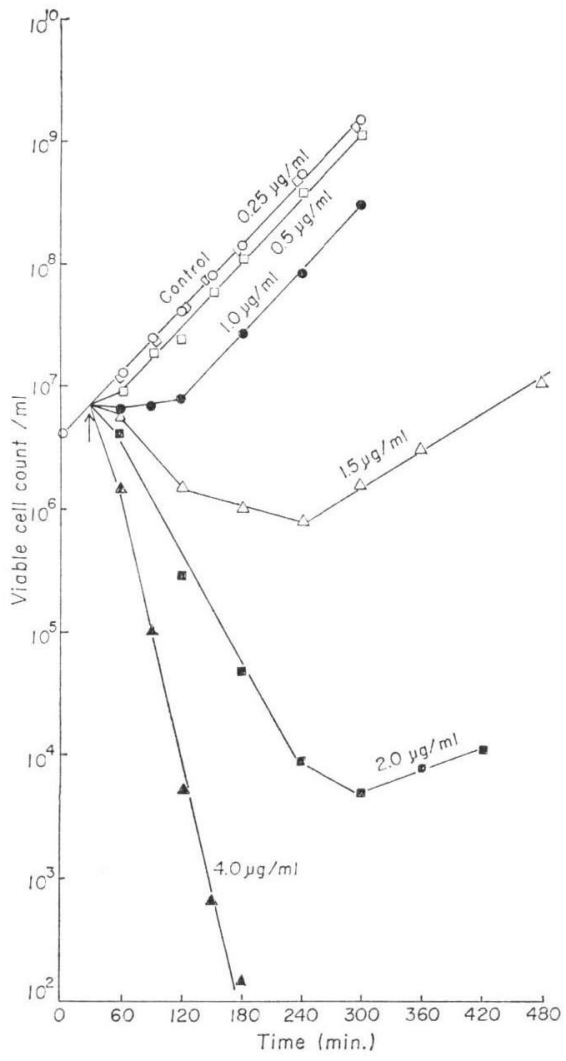

Fig. 3. Plot of the difference between the generation rate of $E$. coli in the absence of ampicillin $\left(k_{o}\right)$ and the apparent generation rate in the presence of ampicillin $\left(k_{a}\right)$ as a function of ampicillin concentration.

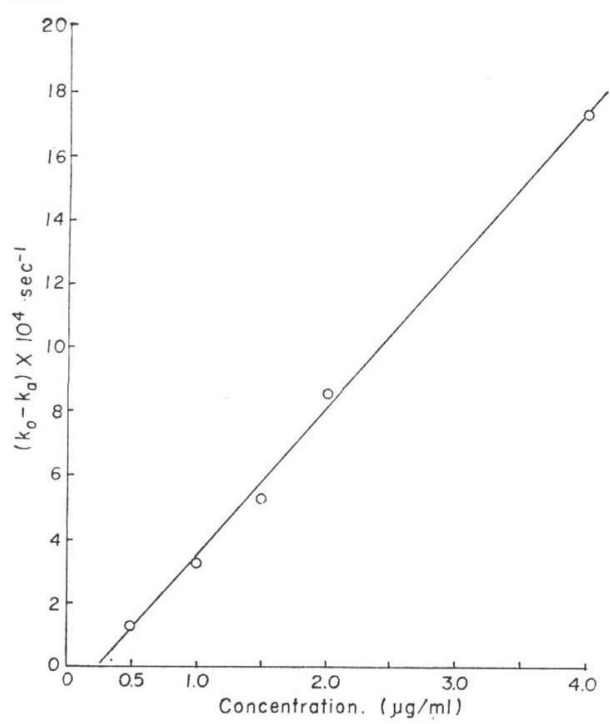

Fig. 2. Survivors number ratios of ampicillin-free culture of $E$. coli $\left(S_{f}\right)$ to the culture with different concentrations $(0.5,1.0,1.5,2.0$ and $4.0 \mu \mathrm{g} / \mathrm{ml})$ of ampicillin $\left(S_{a}\right)$ in relation to time.

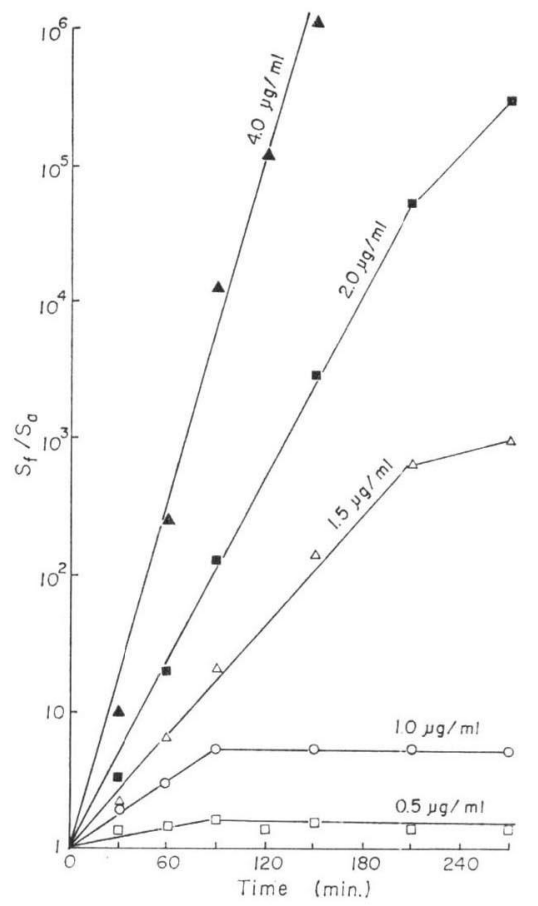

Fig. 4. Dependence of the apparent generation rate $\left(k_{a}\right)$ of $E$. coli on the ampicillin concentration in the culture medium.

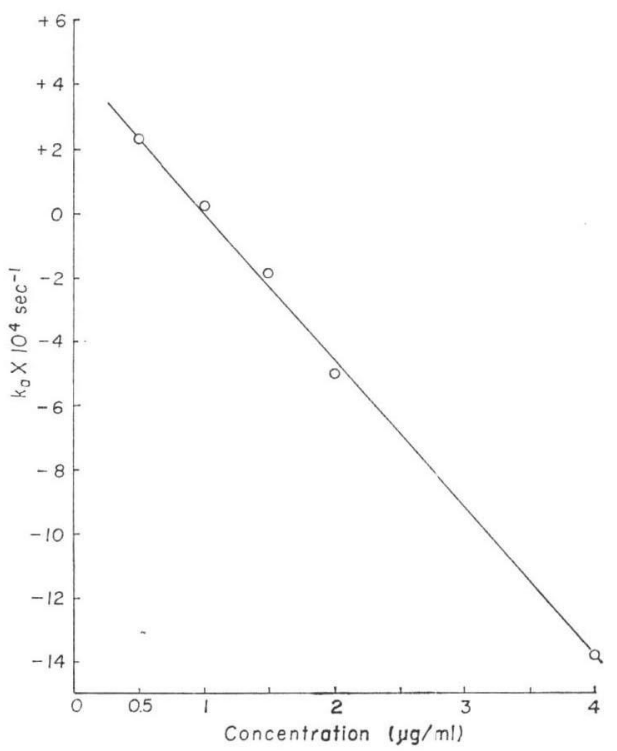


spheroplasts is shown in Fig. 5. In the absence of ampicillin, the viable count followed a logarithmic relation with a generation rate $=6.24 \times 10^{-4} \mathrm{sec}^{-1}$. This rate was nearly double that of the normal cells, $3.6 \times 10^{-4} \mathrm{sec}^{-1}$. Providing that the reverted cells multiplied at the same rate as the normal cells,

Fig. 5. Generation-time curves of $E$. coli spheroplasts in the absence and in the presence of 2,4 , 10,20 , and $100 \mu \mathrm{g} / \mathrm{ml}$ ampicillin.

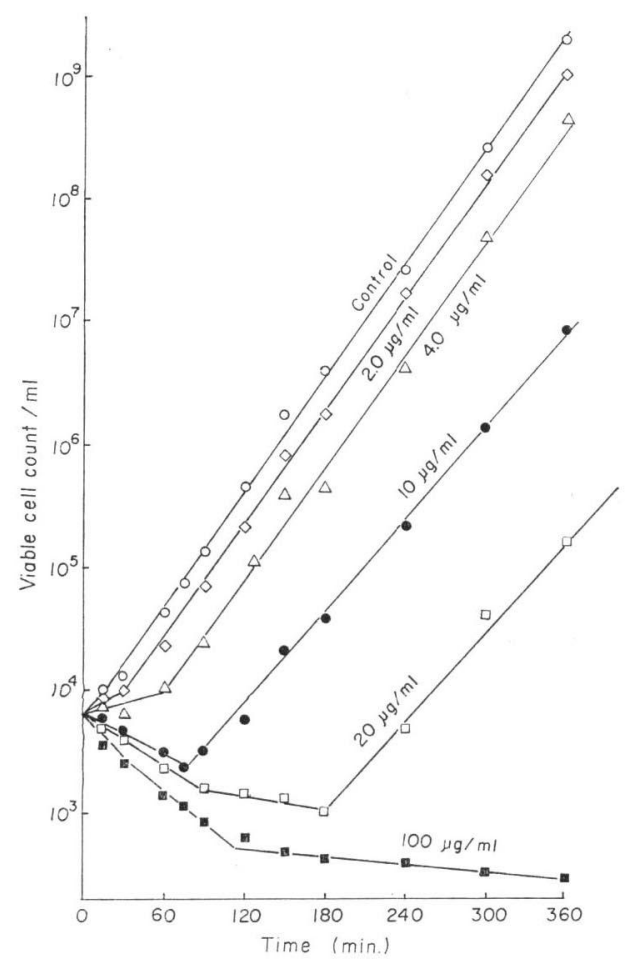

Fig. 7. Plot of the difference between the generation rate of $E$. coli spheroplasts in the absence of ampicillin $\left(k_{0}\right)$ and the apparent generation rates in the presence of ampicillin $\left(k_{a}\right)$ as a function of ampicillin concentration.

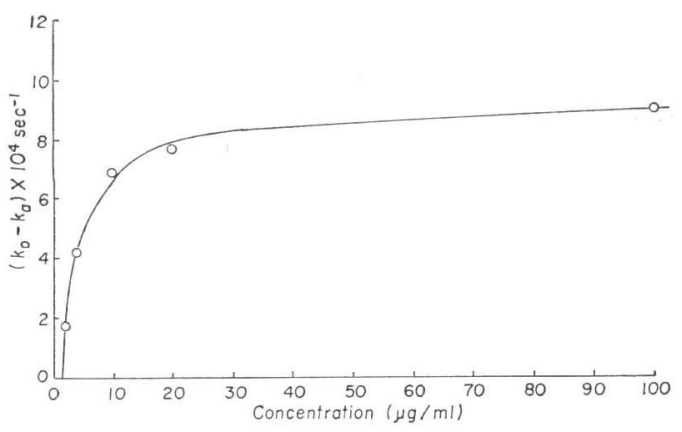

Fig. 6. Survivors number ratios of ampicillin-free culture of $E$. coli spheroplasts $\left(S_{f}\right)$ to the culture with different concentrations $(2,4,10,20$ and $100 \mu \mathrm{g} / \mathrm{ml})$ of ampicillin $\left(S_{a}\right)$ in relation to time.

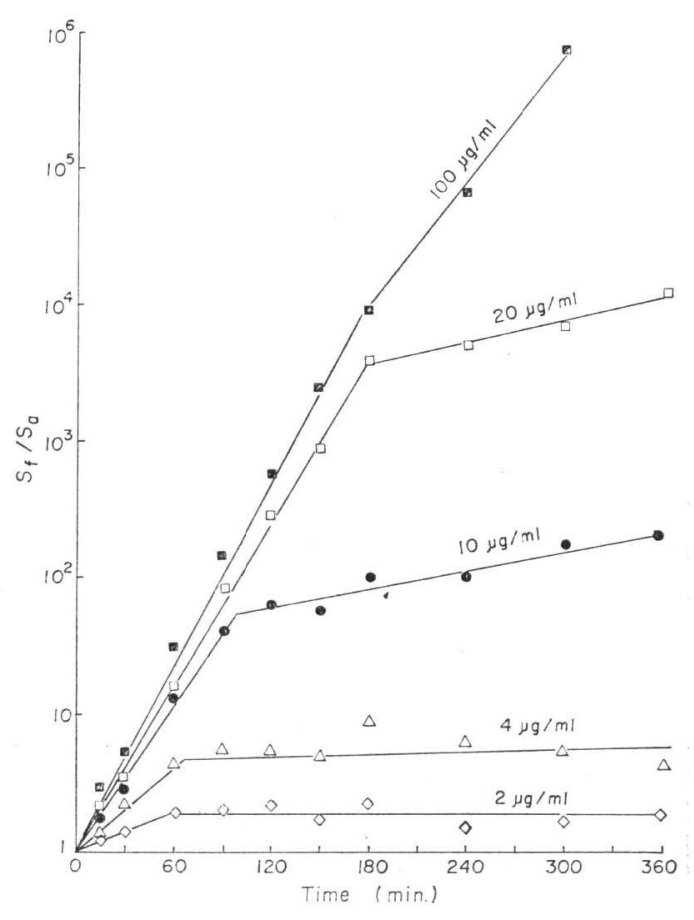

Fig. 8. Dependence of the apparent generation rate $\left(k_{a}\right)$ of $E$. coli spheroplasts on the ampicillin concentration in the culture medium.

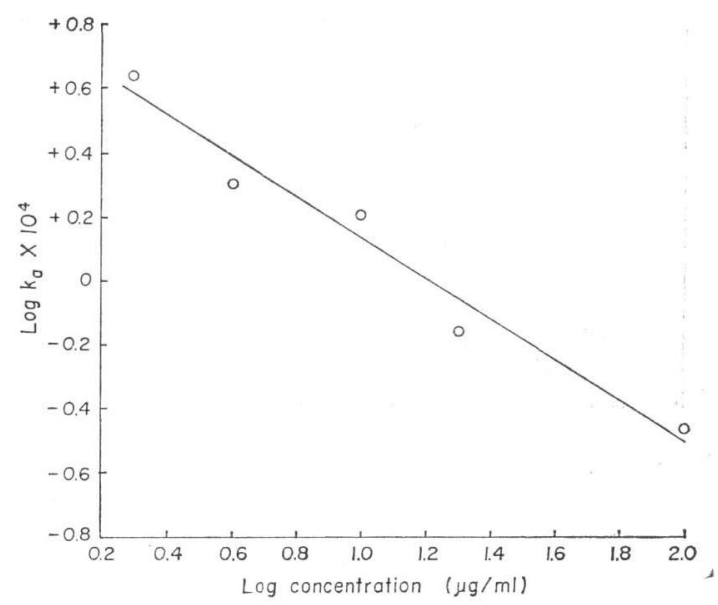


then the difference between the two rates is the apparent reversion rate of the spheroplasts and $=2.84 \times$ $10^{-4} \mathrm{sec}^{-1}$. In the presence of ampicillin, the generation rate did not change upto $10 \mu \mathrm{g} / \mathrm{ml}$ concentrations but the growth was preceeded by a lag period which varied according to the ampicillin concentration. At ampicillin concentrations above $10 \mu \mathrm{g} / \mathrm{ml}$, the growth was preceeded by a period during which the viable count was decreasing with a rate depending upon the ampicillin concentration.

\section{Scanning Electron-microscopy of Ampicillin-treated E. coli and their Treated Spheroplasts}

Samples of E. coli cells taken during their growth in the absence of ampicillin as well as after 1-hour contact with different concentrations of ampicillin were examined under the Stereoscan 600 (Cambridge). Electron-micrographs of untreated and ampicillin-treated E. coli are presented in Plates 1 and 2. With E. coli spheroplasts, electron micrographs showing the shape of the E. coli spheroplasts (Plate 3) and the effect of ampicillin at $100 \mu \mathrm{g} / \mathrm{ml}$ concentrations on the integrity of the spheroplasts (Plate 4) are presented.

Plate 1. Electron micrograph of untreated E. coli cells during their growth. $\times 2,000$.

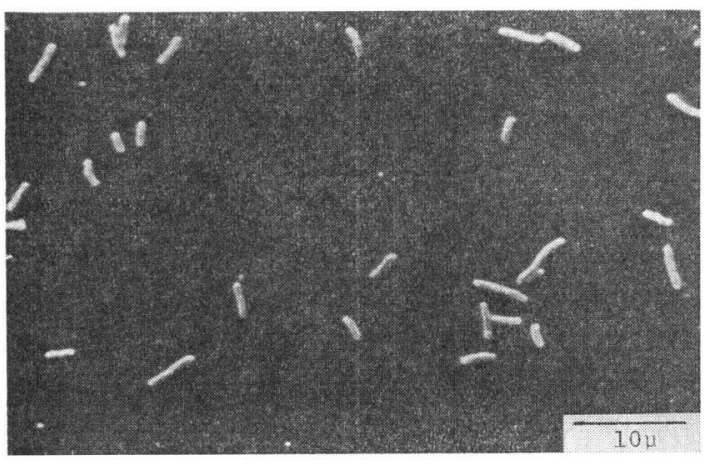

Plate 3. Electron micrograph of E. coli spheroplasts. $\times 5,000$.

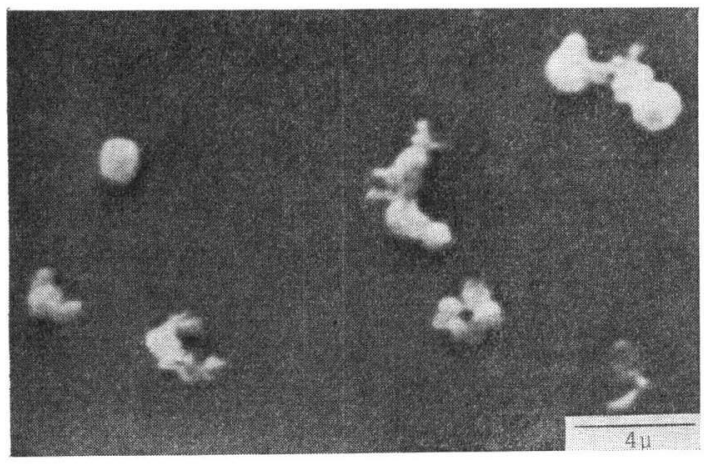

Plate 2. Electron micrograph of E. coli growing cells treated with $1.5 \mu \mathrm{g} / \mathrm{ml}$ ampicillin, showing emergent spheroplast. $\times 10,000$.

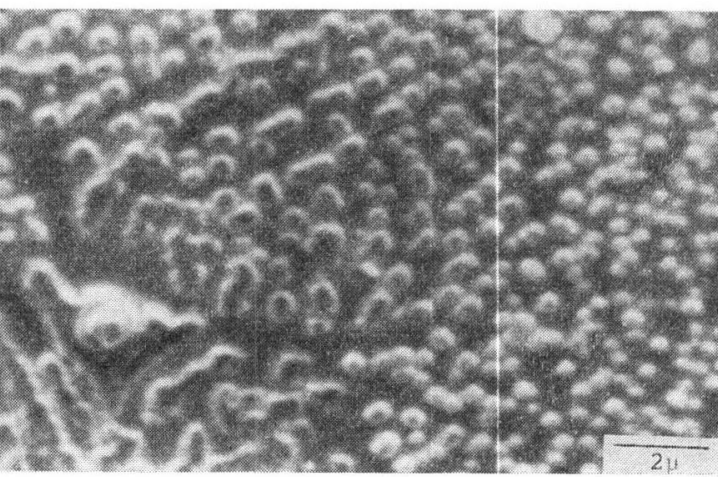

Plate 4. Electron micrograph showing the effect of ampicillin at $100 \mu \mathrm{g} / \mathrm{ml}$ on the integrity of the $E$. coli spheroplasts. $\times 5,000$.

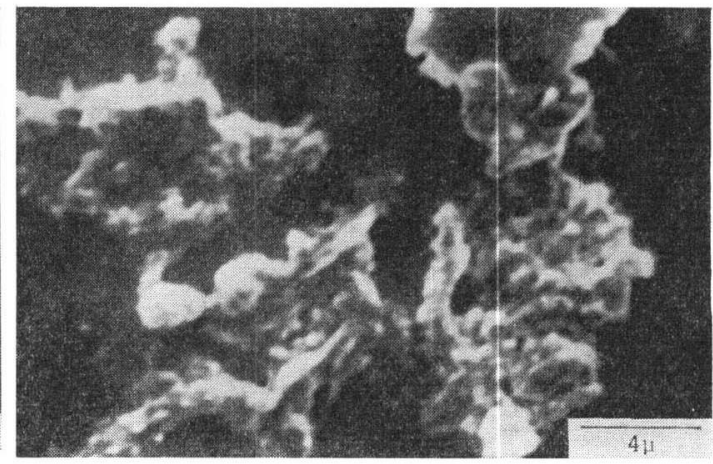

Discussion

Although ampicillin with $E$. coli cells was present at concentrations below the MIC, it was however taken by the cells and exerts its effect after a short time of contact (15 minutes), as indicated by the re- 
duction in the survivors number or by the lag phase in Fig. 1. Ampicillin at $0.25 \mu \mathrm{g} / \mathrm{ml}$ has no harmful effect while at concentrations $1.5,2.0$ and $4.0 \mu \mathrm{g} / \mathrm{ml}$ exhibited a bactericidal effect as appeared from the reduction of the viable counts. This could be explained from the electroscanning microscope studies. Those cultures exhibiting reduction in the viable counts have shown some spheroplasts under the electron microscope, while culture containing $1.0 \mu \mathrm{g} / \mathrm{ml}$ and lower concentrations have not shown any spheroplasts. Such results, therefore, indicate that the loss of viability is directly associated with the formation of spheroplasts.

The kinetics of the effect of ampicillin at the tested concentrations on growing bacteria could determine the order of the reaction possibly involved with the formation of the spheroplasts. When the logarithm of the ratio $S_{f} / S_{a}$ was plotted against time, straight line relations were obtained. The slope of each represents the value $\left(k_{0}-k_{a}\right)$, which when plotted against the ampicillin concentration produced a straight line (Fig. 3). Also, the plot of $k_{a}$ versus concentration (Fig. 4) is linear and means that the order of reaction involved is a first order.

In Fig. 3, the intersection of the straight line with the abscissa gives the concentration of ampicillin at which $\left(k_{0}-k_{a}\right)=0$, this was $0.25 \mu \mathrm{g} / \mathrm{ml}$. This concentration is in agreement with the experimental results using ampicillin at this concentration (Fig. 1). While the intersection of the straight line in Fig. 4 with the abscissa gives the concentration at which $k_{a}=0$. This concentration was $1.05 \mu \mathrm{g} / \mathrm{ml}$ and represents the minimum lethal concentration. At higher ampicillin concentrations, $k_{a}$ has a negative sign, which indicates the reduction in the viable count from the original count due to the effect of ampicillin. It is clear from the results obtained that when the ampicillin concentration exceeds $4 \mu \mathrm{g} / \mathrm{ml}$ the culture maintained a bactericidal effect which persists until all the cells were converted into spheroplasts and lysed.

The effect of ampicillin concentration on $E$. coli spheroplasts was different from that on normal cells. With $E$. coli spheroplasts, higher ampicillin concentrations were required in order to detect reduction in the viable counts. The results obtained from the kinetics studies were also of different behaviour. The sensitivity of the spheroplasts to ampicillin action was much lower than the bacterial cells, as indicated by the apparent generation and degeneration rates for both (Table 1). It is interesting to notice also that the plot of $\left(k_{a}-k_{0}\right)$ in case of spheroplasts fit a curve (Fig. 7) and not a straight line as it was with normal cells (Fig. 3). This difference in response could indicate that ampicillin acts on the spheroplasts through different receptor sites. Further proof is the lower order of response obtained when $\log k_{a}$ was plotted against $\log$ concentration (Fig. 8), this was 0.634 . The most likely explanation for the effect exerted by ampicillin on the spheroplasts, which is a concentration dependence, is the suggestion given by $\mathrm{PARK}^{13 \text { ? }}$ who considered the culture of penicillinspheroplasts to be consisted of a mixture of different stages defected cell-wall cells; some cells were with completely deficient murein sacculus $^{14)}$, and the others were with partially defected cross-linked murein sacculus. It was the latter type of cells which was affected by the ampicillin and require therefore high concentrations of the antibiotic.

Another effect of ampicillin on the spheroplasts which was observed by the electroscanning microscope, was the damage occurred to them by high ampicillin concentrations (Plate 4). At 100

Table 1. Effect of ampicillin concentration on the apparent generation rate $\left(k_{a}\right)$ of $E$. coli cells and $E$. coli spheroplasts.

\begin{tabular}{r|c|c}
\hline \multirow{2}{*}{$\begin{array}{c}\text { Ampicillin } \\
\mu \mathrm{g} / \mathrm{ml}\end{array}$} & \multicolumn{2}{|c}{$\left(k_{a}\right) \mathrm{sec}^{-1}$} \\
\cline { 2 - 3 } & Bacterial cells & Spheroplasts \\
\hline 0.0 & $3.6 \times 10^{-4}$ & $6.2 \times 10^{-4}$ \\
0.5 & $2.3 \times 10^{-4}$ & - \\
1.0 & $0.3 \times 10^{-4}$ & - \\
1.5 & $-1.7 \times 10^{-4}$ & - \\
2.0 & $-5.0 \times 10^{-4}$ & $4.4 \times 10^{-4}$ \\
4.0 & $-13.8 \times 10^{-4}$ & $2.0 \times 10^{-4}$ \\
10.0 & - & $-0.6 \times 10^{-4}$ \\
20.0 & - & $-1.4 \times 10^{-4}$ \\
100.0 & - & $-2.9 \times 10^{-4}$ \\
\hline
\end{tabular}
$\mu \mathrm{g} / \mathrm{ml}$ ampicillin concentration, the spheroplasts were completely ruptured and cell fragments were observed. The actual mechanism involved to produce this effect is not quite clear, however, it may be due to a direct action of ampicillin on the protoplast membrane resulting in their lyses, an effect which was not exhibited by benzyl penicillin. 
Acknowledgement

Dr. A. E. Elkhouly is indebted to the Alexander von Humboldt Foundation for the award of the fellowship.

\section{References}

1) Brown, M. R. W. \& E. R. Garrett: Kinetics and mechanisms of action of antibiotics on microorganisms. I. Reproducibility of Escherichia coli growth curves and dependence upon tetracycline concentration. J. Pharm. Sci. 53: 179 183, 1964

2) Garret, E. R.; G. H. Miller \& M. R. W. Brown: Kinetics and mechanisms of action of antibiotics on microorganisms. V. Chloramphenicol and tetracycline affected Escherichia coli generation rates. J. Pharm. Sci. 55: 593 600, 1966

3) Garrett, E. R. \& O. K. Wright: Kinetics and mechanisms of action of drugs on microorganisms. VII. Quantitative adherence of sulfonamide action on microbial growth to a receptor-site model. J. Pharm. Sci. 56: 1576 1585, 1967

4) Garrett, E. R. \& H. Nolte: Kinetics and mechanisms of drug action on microorganisms. XIV. The action of fluorouracil, other uracils and derived nucleosides on the microbial kinetics of Escherichia coli. Chemotherapy 17: 81 108, 1972

5) Garrett, E. R. \& A. J. Richard: Kinetics and mechanisms of drug action on microorganisms. XX. Integrated receptor site model rationalizing observed microbial rate dependences on drug concentration and microbial kinetics affected by sodium fusidate. J. Pharm. Sci. 63: 884 894, 1974

6) Miller, G. H.; S. A. Khalil \& A. N. Martin: Structure-activity relationships of tetracyclines. I. Inhibition of cell division and protein and nucleic acid syntheses in Escherichia coli. J. Pharm. Sci. 60: 33 40, 1971

7) Heman-AcKaH, S. M.: Microbial kinetics of drug action against Gram-positive and Gram-negative organisms. I. Effect of lincomycin on Staphylococcus aureus and Escherichia coli. J. Pharm. Sci. 63: 1077 1084, 1974

8) Richards, J. P. \& A. E. Elkhouly: The recovery of phenylmercuric nitrate-treated bacteria using sodium thioglycolate. J. Pharm. Pharmac. 19: Suppl. 209S 215S, 1967

9) Greenwood, D. \& F. O'Grady: A comparison of the effects of ampicillin on Escherichia coli and Proteus mirabilis. J. Med. Microb. 2: 435 441, 1969

10) Auhagen, E.; Ch. Gloxhulber, G. Hecht, Th. Knott, H. Otten, E. Rauenbusch, K. H. Risse, J. Schmid, W. Scholtan \& A. M. Walter: Ampicillin-Binotal, a broad-spectrum penicillin. Arzneimittel-Forsch. 12: $791 \sim 801,1962$

11) Speicer, A. B. \& D. F. Spooner: The inhibition of growth of Escherichia coli spheroplasts by antibacterial agents. J. Gen. Microbiol. 30: 37 50, 1974

12) Lederberg, J.: Bacterial protoplasts induced by penicillin. Proc. Nat. Acad. Sci. U. S. 42: 574 577, 1956

13) Park, J. T.: 16th Symposium of the Soc. Gen. Microbiology, p. 79, 1965

14) Park, J. T. \& J. L. Strominger: Mode of action of penicillin. Science 125: 99 101, 1957

15) Hirokawa, H.: Biochemical and cytological observations during the reversing process from spheroplasts to rod-form cells in Escherichia coli. J. Bacteriol. 84: 1161 1168, 1962

16) Hirokawa, H.: Properties of rod cells reversed from penicillin spheroplasts in Escherichia coli. J. Bacteriol. 91 : $125 \sim 128,1966$ 